\title{
E-WoM and Destination Image: How Does It Affect the Revisit Intention at English Village
}

\author{
Muhammad Dian Ruhamak ${ }^{1,}$ Nindi Vaulia Puspita ${ }^{2}$,Yudiarto Perdana Putra ${ }^{3}$ \\ ${ }^{1}$ Departement of Economics, Kadiri University, East Java, Indonesia ${ }^{2}$ Departement of Economics, Kadiri University, East \\ Java, Indonesia ${ }^{3}$ Departement of Economics, Kadiri University, East Java, Indonesia
}

"Corresponding author.dianru@unik-kediri.ac.id

\begin{abstract}
Based on current developments on how to attract consumers' interest in wanting to visit education-based tourism destinations, this study aims to determine the effect of e-wom and destination images on the revisit intention inthe English village of Pare - Kediri. Because many migrants take courses from outside the region, the populationin this study are course participants from outside the area with a sample determination of 100 respondents. In the data collection questionnaire and literature study are used. For testing, the data used the instrument validityand reliability analysis, followed by multiple linear regression analysis. Next, test the hypothesis and the coefficient of determination. From the testing of the instrument, the results were obtained that all questionnaire items were declared valid and reliable. Hypothesis test results show that all hypotheses were accepted, as evidenced by the calculated $t$ value of from 4,781> 1.98 and destination image 3,379>1.98 and the estimated fvalue of 26,240> 3,089. the coefficient of determination shows that revisit intention can be explained by e-wom and destination image by $35.3 \%$.
\end{abstract}

Keywords: E-WoM, Destination Image, Revisit Intention.

\section{INTRODUCTION}

English is an important requirement in facing competition both in the business world and education [1]. So since starting training in elementary schools have begun to be introduced to English. But sometimes the portion of learningin schools is still felt to be lacking, so it is deemed necessary to add alternatives to improve English language skills so thatit is better to find a course institution, where one of the favorite destinations of choice is Kampung Inggris in Kediridistrict.

The course institute in the English Village was first established by Mr. Kalend Osen [2] won the title as an educational tour because more than one hundred institutions that stand in that location. Various methods are used in obtaining information ranging from looking at social networks, text, images, and videos on the website used by each institution in marketing their products. Some consumers visit the English village directly to find out howthe learning methods are applied by the institute so that consumers can make the right choice.

The Revisit Intention directly to an English village is influenced by several factors taken into consideration, including destination image, which is a combination of product variations, attractions, and attributes that are added to the impression of the selection process based on various information [3], Revisit intention which is the adoption of repurchase intention is included in one of the post- purchase behavior [4]. In addition, the destination image is a person's perception of products, objects, behaviors, and events that are driven by beliefs, feelings, and a series of goals that have ideas and expectations for a particular place or trip [5]. The experience shared by people who 
have studied in English villages through stories, websites and social media where the information is quickly spread and accessed so easily that indirectly helps market the institution to be better known by consumers where this method of marketing via the internet is now known as e - wom [6].

A good review is based on a feeling of satisfaction felt by consumers where the more satisfied consumers, the reviews given will get better, and vice versa, the more dissatisfied consumers, the worse the reviews provided [7].

Kampung Inggris is located between Pelem and Tulungrejo Villages, Pare District, Kediri Regency, East Java Province. Kampung Inggris received the title as educational tourism because more than one hundred course institutions are standing in that location [8]. In addition, there are also other tours that are located around the location, including the temple Surowono and Tegowangi, bathing surowono, monument intersection of five gumul and so forth that can attract consumers to visit. Consumers must be clever in choosing the right institution, in addition, the program offered by the institution must be varied, which can create an impression for consumers so that it will have an impact on the interestof visiting again.

The formulation of the problem in this study is how the Influence of Destination Imagery and E-WOM on Revisit intention in the English Village in the Kediri Regency.

The purpose of this study was to analyze the Effect of Destination Imagery and E-WOM on Revisit intention in English Village Education Tourism in the Kediri Regency. The selection of the English village was chosen as the object of research because the development of the tourism village is currently attracting visitors in various places throughout Indonesia so that the local government maximizes the potential in the region by forming a tourism icon that is an attraction for local and foreign tourists

\section{THEORY STUDY}

\subsection{Electronic Word of Mouth}

Understanding the Electronic Word of Mouth put forward by Mowen and Minor in [9] expressing a word of mouth communication is the opinion of several people and the exchange of opinions with each other.

Electronic Word of Mouth (eWOM) is a form of marketing communication that contains positive or negative statements made by potential and former consumers about a product that is available to many people through internet social media. [10].

Electronic word of mouth is a very important place for consumers to give their opinions and is considered more effective than word of mouth because of the level of accessibility and wider range than traditional word of mouththat has offline media.[11][12]
The difference between the traditional word of mouth and electronic word of mouth lies in the media used, the range of information, the range of communication with fellow internet users, and the receipt of information [13].

\subsection{Destination Image}

Place imagery is an interactive thought system of opinions, feelings, visualizations, and intentions towards a destination[14].

Destination imagery according to Lawson and Bovy in [15] defines that "destination image is a concept as the expression of all objectives knowledge, prejudices, imagination and emotional thoughts of an individual or group about a particular location,"

The image of the place can influence tourists in deciding the trip, behavior at the destination as well as the level of satisfaction and memory of the experience, image representation of the area offered to tourists feels less important than the existence of a picture on the person's mind. [16].

The image of the place is an important factor of the destination visit as a good image of the destination to bringmore tourists to the tourist destination [17].

Destination image is a decision of a journey of individual thought in the form of knowledge, feelings, and perceptions into the overall goal, thinking of the experience based on the level of visitor satisfaction with the destination visited. Satisfaction [18]

\subsection{Revisit Intention}

Interest in visiting, according to kanuk, in [19] is a driving force that causes someone to pay attention to other people or to other objects.

Revisit intention is defined as an important factor for continuing to create company profits or performance froma long-term perspective [20]

Interest is one source of motivation for someone to do activities that are preferred that will have an impact on increasing market share. There are 3 (three) factors that cancause someone's interest, namely the factor of encouragement from within, social motive factors and emotional factors

\subsection{Literature Review}

Research result [21] Shows That Partial Accessibility, Experiential Marketing, Word Of Mouth Electronics Has A Significant Effect On Customer Satisfaction. While Simultaneous Accessibility, Experiential Marketing, and Word of Mouth Electronics have a Significant Effect on Customer Satisfaction.

Research result [22] shows that the uniqueness of Tourism Services has a Significant Impact on Destination Image, Destination Image has a Significant Effect on Intention to Revisit, and the Uniqueness of Tourism Services has a Significant Effect on Revisit Intention. 
The research from [5] findings verify the mediating role of a holistic image for predicting tourists' intention to revisit a destination, supporting a partial and a full mediation. Interestingly, only affective and conative images contribute to the prediction of tourists' intention to revisit a destination through the holistic image towards this destination. Moreover, PNBs moderate the effect that conative destination images have on tourists' holistic image. Practically, the research high- lights factors that affect tourists' tendency to select a tourism destination, which can serve as a basis for tailoring the effective positioning of destinations.

Research conducted by [18] found results that Dimg> Rint Received. Shows That Some Things Like Inadequate Infrastructure, Convenience, and Several Other Factors Influence Revisit Intention. Tsat> Rint Has Little Influence Because Expectations Of Travel Destinations Are Not Satisfied or Unsuitable. Dimg> Tsat is Strongly Connectedand Produces the Conclusion That Destination Image plays an important role in Maintaining Tourist Trust in Tourism Setu Babakan.

Research conducted [23] get results (1) Quality of E- Service Has Positive and Significant Effects on ESatisfaction (2) E-Service Quality Has Positive and Significant Effects on E-Word of Mouth (3) ESatisfaction Has Positive and Significant Effects on E Word Of Mouth

(4) E-Word Of Mouth Has A Positive And Significant Effect On Revisit Intention. Conclusion This Analysis Highlights the Positive Effect of Taking Part in E-Service Quality, E-Satisfaction, and E-Word Of Mouth AgainstRevisit Intention.

Research result [24] shows that the direct relationship and indirect relationship between variables (ewom as intervening) are stated significantly. Destination image and service quality are important antecedents for ewom becauseimage and experience can influence the willingness to share. Media in the network are able to attract the attention of tourists because they are able to facilitate them in finding new information quickly and easily so that ewom becomes an effective promotional activity for the promotion of tourist destinations.
From the formulation of the problem and research objectives as well as some of the previous studies that havebeen put forward, there are three hypotheses in this study, including 1) e-wom and destination image have a significant influence on revisit intention. 2) e-wom has a significant effect on revisit intention. 3) destination image has a significant effect on revisit intention

\section{RESEARCH METHOD}

The method used in this research is quantitative research methods. The population in this study are consumers who are taking courses in English villages whose exact numbers are unknown where the formula wibisono is used in [8] by determining the significance level of $5 \%$, a total sample of

96.04 was obtained which was rounded up to 100 respondents [25]. Data collection techniques using probability sampling [26].

In obtaining data from respondents, interviews, literature study, observation, and distributing questionnaires werearranged based on indicators of each variable using a Likertmeasurement scale 1-5. The next stage is that after the datais collected, then the validity test is done which compares the value of $r$ arithmetic with $r$ table where if the value of $r$ arithmetic $>r$ table then the item is said to be valid, and thereliability of the questionnaire is done by looking at the alpha Cronbach's value, if the value is $>0.6$, then the item is reliable. Next multiple regression analysis, hypothesis testing is done with the $\mathrm{F}$ test where if the value of Fcount $>$ Ftable and its significance $<0.05$ then the hypothesis is accepted, as well as the F test, the test criteria are accepted if the value of Tcount $>$ Ttable and the significance $<0.05$ then the hypothesis accepted and the coefficient of determination is done to determine the effect of E-Wom and Destination Image on Revisit Intention which if the value is close to 1 is said to be good, but if it is close to 0 then it is not good.

\section{RESULT}

\section{A. Validity and Reliability Analysis}

For the first test that is to test the validity of each item questionnaire presented in table 1 below

Table 1 Test of Validity

\begin{tabular}{|c|c|c|c|c|c|c|c|}
\hline Item & R Count & R Table & Note & Item & $\begin{array}{c}\mathrm{R} \\
\text { Count }\end{array}$ & R Table & Note \\
\hline $\mathrm{X} 1.1$ & 0.343 & 0.189 & Valid & $\mathrm{X} 2.2$ & 0.845 & 0.189 & Valid \\
\hline $\mathrm{X} 1.2$ & 0.595 & 0.189 & Valid & $\mathrm{X} 2.3$ & 0.569 & 0.189 & Valid \\
\hline X1.3 & 0.784 & 0.189 & Valid & $\mathrm{X} 2.4$ & 0.295 & 0.189 & Valid \\
\hline X1.4 & 0.553 & 0.189 & Valid & Y1.1 & 0.782 & 0.189 & Valid \\
\hline $\mathrm{X} 1.5$ & 0.286 & 0.189 & Valid & Y1.2 & 0.819 & 0.189 & Valid \\
\hline X1.6 & 0.486 & 0.189 & Valid & Y1.3 & 0.386 & 0.189 & Valid \\
\hline $\mathrm{X} 2.1$ & 0.673 & 0.189 & Valid & Y1.4 & 0.452 & 0.189 & Valid \\
\hline
\end{tabular}


From the above table, it can be concluded that all questionnaire items have $r$ count values greater than $r$ table

0.189 . so that all questionnaire items were declared valid. Next is to conduct reliability testing to determine the reliability of the questionnaire used where the test results are presented in Table 2 below

B. Test the Hypothesis

After testing the questionnaire instrument, hypothesis testing is then performed to prove whether the hypothesis is accepted or rejected. Test results are shown in the table below

Table 2. test of reliability

\begin{tabular}{|l|c|c|}
\hline Item & $\begin{array}{c}\text { Alpha } \\
\text { Cronbach's }\end{array}$ & Note \\
\hline E-WoM & 0.698 & ble $^{\text {Relia }}$ \\
\hline Destination Image & 0.732 & ble $^{\text {Relia }}$ \\
\hline Revisit Intention & 0.735 & ble $^{\text {Relia }}$ \\
\hline
\end{tabular}

Source: primary data composed by research (2020)

From the test results in the above table, it can be concluded that all questionnaire items are declared reliable because all Cronbach's alpha values are greater than 0.6.

Table 3 F Test

\begin{tabular}{|cc|c|c|c|c|}
\hline \multicolumn{7}{c|}{ ANOVA $^{\text {a }}$} \\
Model & $\begin{array}{c}\text { Sum of } \\
\text { Squares }\end{array}$ & Df & Mean & & \\
\hline Regression & 261.013 & 2 & 130.506 & 26.420 & $.000^{\text {b }}$ \\
\hline Residual & 479.147 & 97 & 4.940 & & \\
\hline Total & 740.160 & 99 & & & \\
\hline \multicolumn{6}{c|}{ a. Dependent Variable: Revisit Intention } \\
\hline
\end{tabular}

Source: Primary data composed by research (2020)

From the test results obtained that the calculated $\mathrm{f}$ value is 28. greater than $\mathrm{f}$ table 3.080 and the calculated significance value is smaller than 0.05 so that the hypothesis that reads e-wom and destination image affect the revisit intention is accepted

Table 4 T-Test

\begin{tabular}{|c|c|c|c|c|c|}
\hline \multicolumn{6}{|c|}{ Coefficients } \\
\hline \multicolumn{3}{|c|}{ Unstandardized Coefficients } & \multirow{2}{*}{$\begin{array}{c}\text { Standardized } \\
\text { Coefficients } \\
\text { Beta }\end{array}$} & \multirow{2}{*}{$\mathrm{T}$} & \multirow{2}{*}{ Sig. } \\
\hline Model & B & Error & & & \\
\hline (Constant) & 3.243 & 1.811 & & 1.791 & .076 \\
\hline E-WoM & .358 & .075 & .419 & 4.781 & .000 \\
\hline Destination Image & .302 & .089 & .296 & 3.379 & .001 \\
\hline \multicolumn{6}{|c|}{ a. Dependent Variable: Revisit Intention } \\
\hline
\end{tabular}

Source: Primary data composed by research (2020) 
From the t-test table, it can be seen that the results of testing the second hypothesis which reads e-wom have a significanteffect on revisit intention to obtain a $t$ value of 4.781 greaterthan t table 1.98 and the significance value of the count is smaller than 0.05 so that the second hypothesis is accepted.Then for the third hypothesis, the results of the calculation of the value of $t$ arithmetic
3.379 are greater than $t$ table 1.98 , and significance is less than 0.05 so that the hypothesis that states destination image has a significant effect on revisit intention received.

Next to the results of the coefficient of determination can beseen in the table below

Table 5 Determinant Coefficient

\begin{tabular}{|c|c|c|c|c|}
\hline \multicolumn{5}{|c|}{ Model Summary } \\
\hline $\begin{array}{l}\text { Mod } \\
\text { el }\end{array}$ & $\mathrm{R}$ & $\begin{array}{c}\mathrm{R} \\
\text { Square }\end{array}$ & $\begin{array}{c}\text { Adju } \\
\text { sted } \\
\text { R } \\
\text { Square }\end{array}$ & $\begin{array}{c}\text { Std. } \\
\text { Error of } \\
\text { the } \\
\text { Estimate }\end{array}$ \\
\hline 1 & $.594^{\mathrm{a}}$ & .353 & .339 & 2.223 \\
\hline a. Pre & $\mathrm{s}:(\mathrm{Cc}$ & nt), Dest & ation Imaq & e, E-WoM \\
\hline
\end{tabular}

From the table above, it can be seen that the coefficient of determination of the $\mathrm{R}$ square value of 0.353 . this shows that the ability of e-wom and destination image in explaining revisit intention is $35.3 \%$, while the remaining $64.7 \%$ is explained by other variables not used in this study.

\section{CONCLUSION}

Electronic word of mouth has a positive and significant impact on revisit intention, where the more often people discuss and disseminate information and the more reviews expressed by people who have felt or come, the higher the consumer's revisit intention. These results have supported the research of arifudil et al. [27] and Adrian et al. [23], where the better the ewom, the higher the consumer's revisitintention.

Destination image has a positive and significant effect on revisit intention, where the better the destination image, the higher the revisit intention of consumers. These results havesupported the research of Iranita et al. [28], Pratminingsih [17], and Pantou et al. [16] were the better destination image, the higher consumer's revisit intention.

\section{ACKNOWLEDGMENT}

This research is supported by the Ministry of Technology Research / National Research and Innovation Agency and all parties supporting this research can be carried out

\section{REFERENCES}

[1] M. D. Ruhamak and B. Rahayu, "Pengaruh Word Of Mouth Terhadap Purchase Intention Melalui Brand Image Pada Lembaga Kursus
Bahasa Inggris Dynamic English Course Pare," J. Ekon. Univ. Kadiri, vol. 1, no. 2, pp. 188-204, 2016.

[2] ais nurbiyah al-jum'ah, "Kalend Osen, Kampung Inggris, dan Kemudrtadan Berbahasa | Locita," 2018. https://locita.co/tokoh/siapa/kalend-osenkampung-inggris-dan-kemurtadan-berbahasa (accessed Jul. 31, 2019).

[3] H. Whang, S. Yong, and E. Ko, "Pop culture, destination images, and visit intentions: Theory and research on travel motivations of Chinese and Russian tourists," J. Bus. Res., vol. 69, no. 2, pp. 631-641, 2016,

DOI: 10.1016/j.jbusres.2015.06.020.

[4] A. P. M. Som, A. Marzuki, M. Yousefi, and A. N. Abukhalifeh, "Factors Influencing Visitors' Revisit Behavioral Intentions : A Case Study of Sabah , Malaysia," Int. J. Mark. Stud., vol. 4, no. 4, 2012, doi: 10.5539/ijms.v4n4p39.

[5] N. Stylos, C. A. Vassiliadis, V. Bellou, and A. Andronikidis, Destination images, holistic images and personal normative beliefs: Predictors of intention to revisit a destination, vol. 53. 2016.

[6] M. D. Ruhamak, P. Vitasmoro, and A. N. Rahmadi, "The Influence of Testimonial, Social Media-based Promotions and Electronic Word of Mouth toward Purchase Intention," Proc. Annu. Conf. Soc. Sci. Humanit., vol. 1, no. 1, pp.78-81, 2018.

[7] A. N. Rahmadi and M. D. Ruhamak, "Pengaruh Costumer Relationship management (CRM) dan Word Of Mouth (WOM) Terhadap Kinerja Usaha Pada Usaha Kecil dan Menengah di Kota Kediri," Ekonika J. Ekon. Univ. kadiri, vol. 3, no. 2, pp. 208-216, 2018.

[8] M. D. Ruhamak and E. H. Syai'dah, "Pengaruh Word Of Mouth, Minat Konsumen Dan Brand 
Image Terhadap Keputusan Konsumen (Studi Pada Pelajar Lembaga Kursus Di Area Kampung Inggris Pare)," Ekonika J. Ekon. Univ. kadiri, vol. 3, no. 2, p. 14, 2018, doi: 10.30737/ekonika.v3i2.186.

[9] C. Umamy, S. Kumadji, and E. Yulianto, "PENGARUH ELECTRONIC WORD OF MOUTH TERHADAP BRAND IMAGE SERTA DAMPAKNYA PADA MINAT BELI ( Survei pada Mahasiswa Universitas Brawijaya Malang Angkatan 2015 / 2016 Pengguna Smartphone )," J. Adm. Bisnis, vol. 33, no. 1, pp. 114-119, 2016.

[10] T. Hennig-Thurau, K. P. Gwinner, G. Walsh, and D. D. Gremler, "Electronic word-of-mouth via consumer-opinion platforms: Whatmotivates consumers to articulate themselves on the Internet?," J. Interact. Mark., vol. 18, no. 1, pp. 38-52, 2004, doi: 10.1002/dir.10073.

[11] M. R. Jalilvand and N. Samiei, "The effect of electronic word of mouth on brand image and purchase intention: An empirical study in the automobile industry in Iran," Mark. Intell. Plan., vol. 30, no. 4, pp. 460-476, 2012, doi: 10.1108/02634501211231946.

[12] S. Doosti, M. R. Jalilvand, A. Asadi, J. Khazaei Pool, and P. Mehrani Adl, "Analyzing the influence of electronic word of mouth on visit intention: the mediating role of tourists' attitude and city image," Int. J. Tour. Cities, vol. 2, no. 2, pp. 137-148, 2016, doi: 10.1108/IJTC-12-20150031.

[13] E. Jeong and S. S. Jang, "Restaurant experiences triggering positive electronic word-of-mouth (eWOM) motivations," Int. J. Hosp. Manag., vol. 30, no. 2, pp. 356-366, 2011.

[14] R. Rajesh, "Impact of Tourist Perceptions, Destination Image and Tourist Satisfaction on Destination Loyalty: A Conceptual Model," PASOS. Rev. Tur. y Patrim. Cult., vol. 11, no. 3, pp. 67-78, 2013, doi: 10.25145/j.pasos.2013.11.039.

[15] S. D. F. Lopes, "Destination image: Origins, Developments and Implications," PASOS. Rev. Tur. y Patrim. Cult., vol. 9, no. 2, pp. 305-315, 2011, doi: 10.25145/j.pasos.2011.09.027.

[16] P. Pantouw and S. S. Pangemanan, "The Effect Of Destination Image And Tourist Satisfaction On Intention To Revisit In Lembeh Hill Resort," $E M B A$, vol. 2, no. 3, pp. 49-57, 2014, doi: 10.1080/14768320500230185.

[17] S. A. Pratminingsih, C. L. Rudatin, and T. Rimenta, "Roles of Motivation and Destination Image in Predicting Tourist Revisit Intention: A Case of Bandung - Indonesia," Int. J. Innov. Manag. Technol., vol. 5, no. 1, 2014, DOI: 10.7763/ijimt.2014.v5.479.

[18] S. F. Wibowo, "The Influence Of Destination Image And Tourist Satisfaction Toward Revisit Intention Of Setu Babakan Betawi Cultural Village," J. Ris. Manaj. Sains Indones., vol. 7, no. 1, pp. 136-156, 2016.

[19] K. G. Widagdyo, "Pemasaran, Daya Tarik Ekowisata, dan Minat Berkunjung Wisatawan," Esensi J. Bisnis dan Manaj., vol. 7, no. 2, pp. 261-276, 2017, doi: 10.15408/ess.v7i2.5411.

[20] J. Hyunjin, "The Effect of Experiential Marketing on Customer Satisfaction and Revisit Intention of Beauty Salon Franchise Stores," vol. 17, no. 3, pp. 109-121, 2013.

[21] D. Tantriana and Widiartanto, "Pengaruh Aksesibilitas , Experiential Marketing Dan Electronic Word Of Mouth ( eWOM ) Terhadap Keputusan Berkunjung Kembali Melalui Customer Satisfaction,"pp. 1-11, 2017.

[22] F. Destari, "Meningkatkan Intention To Revisit Melalui Keunikan Jasa Pariwisata \& Destination Image," J. Manaj. dan Kearifan Lokal Indones., vol. 1, no. 1, p. 44, 2017, doi: 10.26805/jmkli.v1i1.4.

[23] J. Andrian and O. Trinanda, "The Influence Of EService Quality, E- Satisfaction, And E-Word Of Mouth Toward Revisit Intention On Tokopedia Website In Padang City,"EcoGen, vol. 2, no. 2, pp. 69-77, 2019.

[24] R. R. Prayoga and A. Kusumawardhani, "Examining Relationships of Destination Image

, Service Quality , e-WOM , and Revisit Intention to Sabang Island , Indonesia," Asia- Pacific Manag. Bus. Appl., vol. 5, no. 2, pp. 85-96, 2016.

[25] M. D. Ruhamak, S. Utami, and M. Andarini, "The Influence of Service Quality and CRM on Patient Satisfaction (Clinical Studies at DKT Nganjuk Health Clinic)," vol. 383, no. Icss, pp. 497-500, 2019, doi: 10.2991/icss-19.2019.33.

[26] Sugiyono, Metode Penelitian dan Pengembangan (Research andDevelopment/R\&D). 2016.

[27] R. R. Arifuddin, A. R. Kadir, and N. Kadir, "The Influence of Electronic Word of Mouth and Attractiveness Towards Revisit Intention With Visiting Decision as an Intervening Variable (Case Study on Tourists in Makassar City),"

[28] Hasanuddin J. Appl. Bus. Entrep., vol. 2, no. 3, pp. 92-108, 2019.

[29] I. Iranita and P. Alamsyah, "Pengaruh citra destinasi, aksessibilitas wisata terhadap minat kunjung ulang wisatawan ke wisata bahari desa benan," J. Bahtera Inov., vol. 2, no. 2, pp. 2028, 2019. 